\title{
The 1786 Acquisition of Pulau Pinang: Unveiling the Light Letters, Revisiting Legal History Case Materials and R. Bonney's Kedah 1771-1821
}

\author{
*AHMAD MURAD MERICAN ${ }^{1}$ \\ ABD UR-RAHMAN MOHAMED AMIN² \\ ${ }^{1}$ International Institute of Islamic Thought and Civilization, International Islamic \\ University Malaysia (ISTAC-IIUM), 50480 Kuala Lumpur, Malaysia \\ ${ }^{2}$ Department of Management and Humanities, Universiti Teknologi PETRONAS, \\ 32610 Seri Iskandar, Perak, Malaysia \\ *Corresponding author: ahmadmurad@iium.edu.my
}

Published online: 29 October 2021

To cite this article: Ahmad Murad Merican and Abd Ur-Rahman Mohamed Amin. 2021. The 1786 acquisition of Pulau Pinang: Unveiling the Light Letters, revisiting legal history case materials and R. Bonney's Kedah 1771-1821. KEMANUSIAAN the Asian Journal of Humanities 28(2): 189-212. https://doi.org/10.21315/kajh2021.28.2.8

To link to this article: https://doi.org/10.21315/kajh2021.28.2.8

\begin{abstract}
This article reviews the "acquisition" of Pulau Pinang by Francis Light and the East India Company (EIC) in the year 1786. The discussion centres on the contested history of Pulau Pinang and the collective memory of the Malays. It reveals discussions between Francis Light and the sultans of Kedah on the supposed "acquisition" and sometime leasing of the island to the EIC. It is based on doubts casted by R. Bonney in his 1971 book Kedah 1771-1821: The Search for Security and Independence. This is supported by legal history and the exchanges in the Light Letters between Light and two Kedah rulers. The letters are kept at the Archives of the School of Oriental and African Studies, University of London. This article reveals that there is no agreement of 1786 . However the landing of Light at Tanjong Penaga in 1786 has been legitimised in the historiography prompt and proper. Seen from the absence of any treaty, the "acquisition" of Pulau Pinang by the EIC in that year is treated as "illegal".
\end{abstract}

Keywords and phrases: Pulau Pinang, East India Company, Francis Light, Sultan Abdullah Mukarram Shah, acquisition

\section{Introduction}

The avatar of 1786 was the pivot that defines subsequent discourses on Pulau Pinang. These are reflected in mainstream thinking that the history of Pulau Pinang began from that year. For example, L.A. Mills (1925) in British Malaya 
1824-67 describes the island as a jungle without any inhabitants. The "umbilical cord" was severed with much impropriety and criminality. Colonial crimes are never legitimised as such. This has undeniably framed the narrative with local and indigenous narratives not represented.

Colonialism is a crime against humanity and is never benign. What happened in 1786, was the conquest of Pulau Pinang. It is a colonial crime, a crime nevertheless. Light stole an island, by deceiving the sultan. He breached the sovereignty of the sultanate of Kedah. The British through the East India Company (EIC) and Light, had vandalised the geography, history and identity of Kedah and its people; much inheriting the Vandals, the Germanic tribe of that name who once roamed and plundered (vandalised) Europe in the 4th and 5th centuries.

History textbooks by former colonial nations are either distorted or silent on covert or overt crimes committed on "native" peoples. The non-European world was governed for Europe's own benefit. Colonialism robs identities and ethnicities. It left a whole lot of ethnic and religious problems in the former colonies. European colonialism ushered a kind of practice creating a social-legal structure bearing on the consciousness of the colonised. One example was the result of the British empire's colonisation. This article is not another effort at petty bashing the West. It seeks to understand the dominant past, a narrative of which refuses to go away, a narrative that is "not over", by any means. This article gives a voice that the nation state does not express. It seeks to question images of benevolence and non-violence and the deep structures beneath colonialism. The history of colonialism should be studied and understood. The case on the criminality of the island of Kedah must be revisited and discussed openly.

This article looks at the legal arguments surrounding the acquisition of the island based on R. Bonney (1971) work, cases and the Light Letters. The article attempts to reveal a narrative with the central themes of what Bonney terms as the "diplomatic history" of Kedah.

\section{The Conquest of the West}

The arrival of Vasco da Gama at the port of Calicut on the south-west coast of India on 27th May 1498 marked a turning-point in the history of India and Europe and subsequently of the Malay Archipelago with the fall of Melaka in 1511 and Francis Light's thieving of Pulau Pinang island from Sultan Abdullah Mukarram Shah of Kedah in 1786. The full significance of the European arrival in the Malay Archipelago can be understood with reference to the religious, economic and political urge after the Crusades. 
Pepper was also a great motivating force. The spice that was ranked with gold and precious stones could only be obtained from India and the Malay Archipelago. Thus indispensable and naturally monopolist trade came to be the chief bone of contention in the politics of the Levant and was the most powerful factor in stimulating European expansion in the 15th century (Panikkar 1953, 22). In the decades of European expansion, Spain and Portugal ${ }^{1}$ were not even the most commercially advanced of the European states. Historian Nicholas Tarling (2001) in exploring the causes and consequences European imperialism in Southeast Asia gives another trajectory in his arguments. Men needed motives for undertaking such ventures, he reasons. The Renaissance offered little in terms of information or technology, but it provides the inspiration. On this propensity, the Renaissance was built. It financed the attempts to capture the glories of antiquity. Interestingly and this is a powerful explanation of the colonisation and dominations of Europe and the West over the rest of the world. Colonisation and domination of Europe and the West over the rest of the world is a continuation in the spirit of the new Romans. This persisted in subsequent ventures to the Malay Archipelago.

The role of the state and its links to the Roman spirit must not be underestimated. The Renaissance offered exciting potential, in that it suggested new ways of building the state, utilising Roman law, acquiring Roman precedent, building in Roman style, demonstrating and consolidating power like how the Romans did. Wealth and the east were connected.

\section{A Note on Major Sources}

This article is based on three major sources. These sources have raised doubts over the integrity of the history Pulau Pinang and Kedah. The intricacies of the relations between the EIC, Light and the sultans of Kedah of Pulau Pinang have triggered a revisit as suggested by the article. The uses of the sources are also to complement each other. The authors find that R. Bonney's Kedah 1771-1821: The Search for Security and Independence (1971) presents a strong case against the British. The book was reprinted in 1974. Its use of the various primary documents in the likes of the Sumatra Factory Records, the Straits Settlements Factory Records (India Office Library, Great Britain) and the Straits Settlements Factory Records (National Library, Singapore) gives fresh evidence on the misfortunes of Kedah.

Bonney captures the period between 1770 and especially through 1786 when the EIC's connections were placed in more formal basis, arising from the company's establishment of a settlement in Kedah. The backbone is the Straits Factory Records. Strangely, Bonney's work has not been given the attention it deserves 
viz the question of the acquisition of Pulau Pinang. This article in reemphasising Bonney, has linked it to Salleh Buang's Malaysian Legal History: Cases and Material (2015). This is the second edition. It was first published in 1993.

The book is a compilation of cases and materials presented in the context of the Malaysian legal system and integrating it with Malaysian legal history. Parts one and two of the book deals with the selection of cases and the historical accounts dealing with the Straits Settlements of Pulau Pinang and Melaka and subsequently the Malay states. Chapter 11 of the book on "The Acquisition of Penang" under its Part II Selected Materials used in the context of Bonney's unravelling of doubts and the absence of an 1786 treaty. The "Selected Materials" offer extracts of some of the important treaties and engagements entered by the rulers of the Malay states and the English. It aims to highlight the actual status of the Malay states and the Malay rulers. It brings forth the issues of "legitimacy" or "legality" of British rule and conquest of Malaysia and Pulau Pinang. Significantly, Salleh includes Alfred P. Rubin's thought-provoking book, The International Personality of the Malay Peninsula. A small part has been extracted and included in the compilation.

Finally, to tie the sources together are the largest collection of Malay letters in the world - the Light Letters-catalogued as MS 40320. The letters are part of the Marsden Collection. William Marsden described the letters as Malay correspondence, consisting chiefly of letters from Malay rulers, dignitaries and merchants of the Malay Peninsula, Sumatera, Borneo and nearby islands, addressed to Francis Light and James Scott of Pulo Pinang. The correspondence, mainly between 1771 and 1794, represents an episode of early encounters of the Malays from Sumatera to the eastern part of the Malay Archipelago with the West (Ahmad Murad 2019a, 5, 6). The collection contains some 200 correspondence between Light and the sultans of Kedah. These letters hold the key to what transpired on the acquisition of Pulau Pinang.

The Malay letters, some 1,200 arranged and bound in 11 volumes. It is now reposited at the School of African and Oriental Studies (SOAS), University of London. The label "Francis Light Letters" (henceforth Light Letters) have been used by SOAS since 1916 when it was established.

\section{Modes of Acquisition}

In the context of the issue arising from the acquisition of Pulau Pinang, some explanation of the different connotations are in order. We hereby outline the five meanings of the various modes of the acquisition of a territory drawn from 
Bashiran Begum, Noriah Ramli and Siti Junaidah's (2007) paper "Lifting the Veils: The Mystique (Mistake) of Penang Legal History". ${ }^{2}$

\section{Cession}

Cession of state territory is the transfer of sovereignty over state territory by the owner-state to another state, either partly or wholly of its territory. To constitute a cession, it must be intended that sovereignty will pass. Even acquisition of governmental power exclusively is insufficient if it is done without intention to cede territorial sovereignty. The only form of cession is in the form of treaty between the ceding and the acquiring state. Cession may have been the outcome of peaceable negotiation or of war and may or may not be with compensation. Cession of territory has often been part of a treaty of peace imposed by the victor.

However, a treaty imposed by certain kinds of force is now subject to the rule expressed in the Article 52 of the Vienna Convention on the Law of Treaties, that the treaty is void "if its conclusion has been procured by the threat or use of force in violation of the principles of international law embodied in the Charter of the United Nation"; past treaties of cession must however be subject to the principle of the inter-temporal law. Nevertheless, even though there were hostilities between two states, a boundary treaty, which is the result of peaceful negotiations would not invalid. Cessions may be agreed upon by the interested states from different motives and for different purposes, for instance gift, voluntary merger, transactions analogues to transactions in private business life. Since cession is a form of title transferring, the maxim nemo dat quod non habet (nobody gives what he does not have) applies. In order for the acquiring state to gain title to the territory, the ceding state must be the legitimate owner of the title. Example is the Island of Palmas case whereby the arbitrator held that "...could not transfer more rights than she herself possessed...".

\section{Occupation}

An act of appropriation by a state by which it intentionally acquires sovereignty over such territory as is at the time not under the sovereignty of another state, (i.e., it must be terra nullius). It can only take place by and for a state, it must be a state act, that is, it must be performed in the service of a state, or it must be acknowledged by a state after its performance by ratification. In the case of Island of Palmas case, the arbitrator held that the independent activity of private individuals is of little value in this connection unless it can be shown that they have acted in pursuance of a license or some other authority received from their governments or that in some other way their governments have asserted 
jurisdiction through them. The court also emphasises the intention to act as sovereign in exercising this function in Clipperton Island arbitration and the Eastern Greenland case.

\section{Terra Nullius}

The only territory which can be the object of occupation is that which does not already belong to any state, whether it is uninhabited or inhabited persons whose community is not considered to be a state. For individuals might live on a territory without forming themselves into a state proper exercising sovereignty over such territory. In the Western Sahara case, the court found that since Western Sahara was inhabited by peoples who, if nomadic, were socially and politically organised in tribes and under chiefs competent to represent them and thus, it could not be regarded as a terra nullius.

In order to acquire title to territory, it is not enough that the state's agent have discovered the territory. Discovery gave the state an inchoate title, acting as "a temporary bar to occupation the discovered territory by another state" for a period reasonably sufficient for effectively occupying the discovered territory. If the period lapsed without any attempt by the discovering state to turn it from inchoate into real title of occupation, other state could acquire it. Discovery and formal declaration of possession may only constitute a root of title.

However, title must be perfected by acts of effective occupation. Possession and administration are two essential facts that constitute an effective occupation. A state must continuously and peaceably administer the territory. The extent of the authority which must be asserted and the area over which administration is exercised depend upon the circumstances and in particular the physical characteristics, of the territory in question. As stated in the case of legal status of Eastern Greenland case, in most cases there have been two competing claims and the tribunal has been satisfied with very little in the way of exercise of sovereign rights provided that the other state could not make out a superior claim. They were:

1. Possession: The territory must really be taken into possession by occupying the state. For this purpose, the state must be taken physically under its sway (corpus) with the intention of acquiring sovereignty over it (animus). It normally involves a settlement on the territory accompanied by some formal act, which announces both that the territory has been taken possession of and that the possessor intends to keep it under his sovereignty. 
2. Administration: After the possession, the possessor must establish some kind of administration within a reasonable time or else it will not be an effective occupation.

The exercise of sovereignty must be peaceful in the sense that it is not challenge by any other states. The effective occupation is to be continuous until the critical date and to be governed by inter-temporal law. The territory of any state is obviously not a possible object for occupation, but a state which has been afterwards abandoned, is a possible object of occupation by another state. Sovereignty may be lost by abandonment, namely by failure to exercise state authority over the territory in question with the intention to abandon it. ${ }^{4}$

\section{Accretion}

Addition to its existing territory by reason of natural changes. For example, where an island arises within the internal or territorial sea of a state or where the bed of a river forming the boundary between states shifts imperceptibly by land which has left one bank of river being added to the other, thus it may have the effect of causing the boundary to alter.

\section{Subjugation, conquest and annexation}

Acquisition of territory by conquest followed by annexation and often called title by conquest is one of the modes of acquisition in the period when the making of war was recognised as a sovereign right and it was not illegal. However, conquest alone will not ipso facto make the conquering state the territorial sovereign of the conquered territory, but only if the conqueror, after firmly established the conquest and the state of war coming to the end, then formally annexed the territory.

Formerly, conquest followed by annexation with or without a treaty of cession gives good title to territory. However, now it is subject to the rule expressed in the Article 52 of the Vienna Convention on the Law of Treaties, that the treaty is void "if its conclusion has been procured by the threat or use of force in violation of the principles of international law embodied in the Charter of the United Nation"; past treaties of cession must however be subject to the principle of the inter-temporal law. 


\section{Prescription}

It denotes the acquisition of title to territory by means of de facto exercise of state authority in the mistaken belief that it is part of the territory of the state which is prescribing for it. The exercise of the authority must be undisturbed and not protested against by the state against which it is exercised. In the case of Island of Palmas case, the absence of protests by Spain against Dutch acts. The essential elements of it are peaceful and continuous display of sovereignty like "occupation".

The period of time which must elapse before title is acquired by prescription is not fixed by international law. The general requirements include:

1. The possession must be in the form of actual exercise of "effective occupation".

2. The possession must be peaceful and uninterrupted.

3. The possession must be public, so that other state has knowledge of it.

4. The possession must be for a certain length of time.

\section{Contesting the Acquisition: Revisiting R. Bonney's Kedah 1771-1821}

Kedah 1771-1821: The Search for Security and Independence by R. Bonney provides a narrative much discussed over the last two decades in the context of the contested history of Pulau Pinang. Kedah's decision to lease a part of Pulau Pinang was induced by many factors. These included threats from Siam and Burma and its encounter with the English EIC. The geographical location of Kedah itself is a major factor - being located at the north of the Malay Peninsula and south west of the Ithmus of Kra. Thus, confrontation with her Siamese and Burmese neighbours was inevitable. The history of Kedah has necessarily been influenced and pressured by her geopolitical location. The sultans of Kedah, Sultan Muhammad Jiwa and his son, Sultan Abdullah Mukarram Shah, have been conscious of the policy of isolating Kedah from its neighbours. Although not directly involved in the struggles between Siam and Burma, Kedah's fortunes were closely linked to them (p. 58). But then came along another element in its history - that of Francis Light and the EIC. These later altered the traditional regional balance of power. Pulau Pinang would emerge to be the prize. 
In Chapter Three of his book, Bonney discusses the antecedents that led to the loss of the Kedah island to the British. It centers on the acceptance and rejection on the lease of Pulau Pinang. Sultan Abdullah's willingness to lease the island in August of 1785 was described by Bonney as interesting especially in view of the fact that Kedah had rejected an application for a similar concession by the EIC in September of 1784. The application was made by Thomas Forrest. The rejection was largely determined by the anticipated losses in trade and revenue that Kuala Kedah would suffer by the establishment of a rival trading settlement and in all probability, by fear of Siamese objections as well. ${ }^{5}$ It seems that the application was opposed by Sultan Abdullah's principal adviser and merchant, Dato' Seri Raja. He who was the same person who accepted Light's proposal only after 11 months after he had refused to consider Forrest's proposals. ${ }^{6}$

Nevertheless, Kedah was in a dilemma. Sultan Abdullah was aware of EIC's interest in Pulau Pinang. At the same time, he was fully aware of the Burmese preparations in 1785 for the invasion of Siam. According to Bonney (1965), Light also knew of the Burmese preparations and hoped to exploit the situation to obtain the lease of Pulau Pinang. On the strength of reports reaching Kedah indicating the magnitude of Burmese naval and military preparations, Sultan Abdullah anticipated an overwhelming Burmese victory. ${ }^{7}$ Kedah was too weak to defend herself from the Burmese threat. And it was obvious to the sultan that, if the invasion of Kedah by Burmese forces was to be avoided, he would have to throw his support on the side of Burma. Equally threatening and this can be seen in the Light Letters ${ }^{8}$ also, was the fear that when hostilities did break out, Siam would demand men, arms, ammunition, boats and food supplies from Kedah, an act which would not only inflict a severe drain on Kedah's resources, but which would also prompt the Burmese to seek revenge. On the other hand, if Kedah were to help Burma, Siam would one day seek vengeance and mete out her usual punitive acts of destruction and racial extermination. The dilemma was nothing unique in Kedah's history. It was only more acute (p. 59).

Sultan Abdullah found himself in an explosive situation. Leasing Pulau Pinang could be the solution in return for defensive assistance. This is seen in the letter in which Sultan Abdullah addressed the governor-general of India on 31st August 1785. The letter offers the lease of the island and the conditions he required from the company in return, as follows:

To the 1st Article: This Government will always keep and armed vessel stationed to guard the island of Pinang and the coast adjacent belonging to the King of Queda. 
2nd: All vessels under every domination bound to the port of Queda shall not be interrupted by the Hon'ble company's Agent or any person acting for the Company or under their authority but left entirely to their own free either to trade with the King of Queda or with the agents or subjects of the Hon'ble Company

3rd: The Governor-General and Council on the part of the East India Company will take care that the King of Queda shall not be a sufferer by an English settlement being formed on the island of Pinang. ${ }^{9}$

4th: The Agent of the Hon'ble Company or any person residing on the island of Pinang under the Company's protection shall not make claims upon the King of Queda for debts incurred by the King's relations, Ministers, officers or Rayat [ra'ayat]. But the persons having demands upon any of the King's subjects shall have power to seize the Persons and property of those indebted to them, according to the custom and usage of that country.

5th: All persons residing in the country belonging to the King of Queda who shall become his enemies or commit capital offences against the state shall not be protected by the English. ${ }^{10}$

6th: This article shall be referred for the orders of the English East India Company together with such parts of the King of Queda's requests as company be complied with previous to their consent being obtained.

According to Bonney, Sultan Abdullah was duly unimpressed by the vagueness that shrouded the governor-general's letter and his "Replies" and the lack of guarantees on the question of compensation and the provision of military assistance. The sultan was perturbed by the complete absence of any formal treaty and by the "go-ahead" tone of the letter. And therefore, on 3rd July, Sultan Abdullah summoned Light to Bukit Pinang to clarify matters. Subsequently on 8th July, the sultan persuaded Light to sign a Malay translation of the governorgeneral's letter. But the governor-general has deferred from entering into a treaty with the sultan until an answer should arrive from Europe. As such, the sultan was not willing to allow the company to occupy Pulau Pinang until such time as a formal treaty containing definite provisions for Kedah's defence was signed. Bonney then, among other things made the conclusion that contrary to accepted history, Pulau Pinang was neither leased, granted or ceded by any written treaty or agreement. Sultan Abdullah gave permission to Light for a temporary occupation of the island until such a time as a definite reply was received from the EIC. Hence, it should be emphasised that there was: 
(N)o written treaty, engagement or agreement, or for that matter, drafts of such, were ever drawn up or entered into regarding any territorial transfer, nor is there any trace or reference to any such document in the records. Pulau Pinang was an integral part of Kedah as the East India Company itself acknowledged and by taking formal possession of the island on 11 August 1786, in the name of King George III of England, Light not only committed, by European standards, a breach of international law but cheated Sultan Abdullah as well. He did so without any proper or final treaty or agreement, without a satisfactory reply to the conditions specified by Sultan Abdullah and with full knowledge that he had been allowed to occupy the island on a tentative basis subject to the Company's decision on the provision of protection and on the understanding with Sultan Abdullah that if this protection was not granted, he would withdraw. (pp. 76-77)

Light's declaration of Pulau Pinang was therefore illegal for no such verbal or written permission was given and the company was in effect, in illegal occupation of Kedah territory. In our reading of the historiography, many terms were used to describe the "possession" of the island of Kedah by Light. These include "occupation", "lease", "acquisition" and "cessation". Bonney also describes some of the statements made by British historians and scholars.

He cites Winstedt (1962) in his Malaya and its History, on page 54. Bonney asserts that Winstedt was wrong when he states that Light took formal possession of the island on 17th July (1786). Historian Tregonning (1965) was also in error. In The British in Malaya, he wrongly states that Light "handed over... the company letter, which made reply to the sultan's terms of cession. With this accepted...he sailed then south to Penang...taking formal possession of the island". W.E. Maxwell and W.S. Gibson in Treaties and Engagement Affecting the Malay States and Borneo (1924) and H.P. Clodd's Malaya's First British Pioneer: The Life of Francis Light (1948), like most historians incorrectly refer to Sultan Abdullah's letter to the governor-general and the Governor-General's "Replies" to him as an "Agreement with the King of Queda for the Cession of Prince of Wales Island in 1786". Clodd writes on pages 49 to 50, that the "sultan announced his readiness to sign the Treaty, which in its final form had been worded so far as the vital clauses were concerned in guarded phraseology by the company. With this document duly signed and sealed Light... sailed". Bonney exclaimed that "this is completely erroneous". 


\section{Pulau Pinang in Malaysian legal history}

This section looks into several sources classified as cases and materials. The arguments draw from Chapter 11 of Salleh Buang's Malaysian Legal History: Cases and Material. ${ }^{11}$ The first reference was L.A. Mills (1966), British Malaya 1824-67 (Kuala Lumpur: Oxford University Press). Materials are selected from pages 30,36 to 38 and 42 to 44 .

Mills raised the dispute arising as to the terms in which Pulau Pinang was ceded by the sultan of Kedah. The question was on the morality of the EIC - was it bound or otherwise, to defend the sultan against his enemies and "above all Siam"? This is more than an academic interest, because in 1821 Siam conquered Kedah and expelled the sultan, the company refusing to assist him. In consequence a bitter controversy arose, which raged in the Straits Settlement until about 1845.

The sultan contended that the company had broken its word and in this way, he was supported by "the great majority of non-official Europeans in the Straits and also by several important officials". Of these were John Anderson, Robert Fullerton and Stamford Raffles. On the other hand, according to Mills, the consensus of official opinion in the Straits was that no promise of assistance had been given or implied. This was held by John Crawfurd as "the greatest English authority on Malaya" (Mills 1966). It was also held by Colonel Burney, who negotiated the Anglo-Siamese Treaty of 1826 and Major Low, who was especially concerned with the affairs of Kedah and Siam during his official career at Pulau Pinang, which extended from 1820 to 1840.

Anderson, on the other hand, was supported by Frank Swettenham. The latter held that when the company accepted Pulau Pinang, it knew that the grant was made almost entirely with a view of obtaining its assistance against Burma and Siam. By continuing to hold the island, the directors of the EIC, they were implicitly bound to render assistance in consideration of which it was granted. The company should either assume moral obligations or else evacuate the island. In British Malaya 1824-67, Swettenham stigmatised the company's conduct as "Cowardice... ending in a breach of faith which sullied the British name and weakened its influence with Malays for very many years" (Mills in Salleh 2015, 228).

When the company accepted the cessation of Pulau Pinang in 1786, it negotiated with Kedah as an independent state. Moreover, the government of India was well aware that in principal and in fact the sole, reason for which the grant was made by the sultan, was to obtain the armed assistance of the company. But it was contrary to the Pitt's India Act, which forbade the company to enter into alliances. 
But later, an agreement was arrived at on the demands made by the sultan. So, in 1787, the Government of India decided not to make a defensive alliance with Kedah. Nevertheless, the sultan continued to push for an alliance, only to be refused by the company on any political commitment.

Swettenham's contention is that after the Indian government decided in 1787 not to give assistance in case of invasion, the retention of Pulau Pinang was a breach of an implied, though not a written, obligation. The refusal to form a defensive alliance should have been followed by the evacuation of the territory which had been ceded in the hope of obtaining protection.

M.B. Hooker's The Law of the Straits Settlements: A Commentary (1982) brings attention to the inhabitants of Pulau Pinang. Hooker stated that when Pulau Pinang was first occupied, "it was practically uninhabited; the (First) Charter (of Justice) 1807, says "wholly uninhabited". Another opinion was adopted by Sir Benson Maxwell, in his historic judgement in Regina vs. Willans, viz, that the island was inhabited by four Malay families. Hooker noted that such being the state of affairs at the time of the acquisition, "what was the lex loci?".

Subsequent questions asked were that did the settlers bring with them the law of England then in being on the ground that the settlement was acquired by occupancy? Or was the Malay law of the Kingdom of Kedah to be enforced, on the ground that it was a ceded country and had formed a part of that kingdom? The Privy Council decided that the former is the correct answer. But they lied. This was because, even though in the Regina vs. Willans (1858), the judgement recognised the existence of four Malay families "yet it could not be said to be inhabited". Judge Benson Maxwell described Pulau Pinang as a "desert island". According to Hooker, Maxwell considered "it clear that for 20 and more years after the founding of the Settlement, no known body of laws was in fact recognised as the law of the place". This is unjust and wrong.

In Fatimah vs. Logan and Others (1871), William Hacket disagreed with Maxwell in holding that the island was "virtually uninhabited" and as such that the case fell under the general rule that "when Englishmen stablish themselves in any uninhabited or barbarous country they carry with them the laws and sovereignty of their own country". It is clear that the courts and the colonial judges see the law in their own paradigm. Again, in Ong Cheng Neo vs. Yeap Cheah Jeo and Others (1872), Hooker claimed that the matter was finally settled by the Privy Council as follows: 
With reference to this history [i.e., the history of the Settlement of Penang]. It is really immaterial to consider whether Prince of Wale's Island or as it is called, Penang, should be regarded as ceded or newly settled territory, for there is no trace of any laws having been established there before it was acquired by the EIC. (Hooker in Salleh 2015, 233)

The Privy Council was of the opinion that in either view the "law of England must be taken to be the governing law as far as applicable to the circumstances of the place and modified in its application by these circumstances". Nevertheless,

The native inhabitants expressed a desire that they should be tried and governed under their own laws with the result that in 1792 Captain Light decided upon and carried into effect the committing of the administration of justice in each class to a headman... (Hooker in Salleh 2015, 234)

Hooker erroneously stated that the 6th June 1800 treaty annulled the 1786 agreement. There was no 1786 agreement. With the new treaty, Province Wellesley was possessed from the sultan.

R.O. Winstedt in A History of Malaya (1935), between pages 163 and 170, argued that there was "an indefinite letter" but "no treaty of final cession". He stated that on 17th July 1786, Light landed on Pulau Pinang and on 11th August, in the presence of officers from the Vansittart and Valentine, two of the company's ships which had brought letters from Madras, he hoisted the British flag and "formally took possession of the island" in the name of His Britannic Majesty, christening it "Prince of Wales Island". With the knowledge and connivance of the company, "the sailor-empire-builder was sailing very near the wind. An indefinite letter, instead of a treaty of final cession! A letter inconsistent and vague in defence, the only point that swayed the ruler of Kedah!" (Winstedt in Salleh 2015, 238).

The memory of the sultans of Kedah on the acquisition of Pulau Pinang is consistent. In 1810, when Lord Minto called at Pulau Pinang on his way to conquer Java, the sultan ${ }^{12}$ addressed to him a long letter setting forth his version of the conditions under which Pinang was given to the British. Anderson's comment on this is that:

It was quite inconsistent with reason to suppose, that Pinang was ceded without some very powerful inducement in the way of promises by Mr. Light, which no doubt, in his eagerness to obtain the grant, were 
liberal and almost unlimited and that his inability to perform them was the occasion of much mental suffering to him. (Winstedt in Salleh 2015, 240)

In Salleh (2015) is Rubin's The International Personality of the Malay Peninsula (1974) reference to pages 137 to 149. Rubin argues on the attitudes of the British in justifying their "occupation and defence of this piece of foreign territory, while reserving to themselves the right to determine the extent of the obligations undertaken in return". Rubin agrees that this seems to be noteworthy because it may be doubtful if considering a similar transaction "occurring in Europe would have been considered legally justifiable".

He highlights the inability of the British to classify their acquisition of Pulau Pinang in terms of European concepts if international law. And this resulted immediately in difficulties in making provision for the application of any recognised system of laws within the territory of Pulau Pinang, by depriving the Supreme Government's legal advisers of the resort to principles of reception of law which are usually held applicable to cases of "cession", "conquest" or "occupation of territorium nullius".

On applying laws to the non-British portion of the inhabitants of Pulau Pinang, it can be implied of a British territorial jurisdiction on that "island either as a delegation of authority from the sultan of Kedah or as a prerequisite of British sovereignty". Had Light's authority derived from the sultan, however, there would seem to have been no need to derive the same authority from the Supreme Government. But if Light were acting as an agent of the Supreme Government, then it would appear that the British were asserting a right to govern foreigners in foreign territory, because had Pulau Pinang been regarded as British territory not question could have arisen over the extent to which jurisdiction could be exercised by delegation in the name of the Supreme Government. The irregular acquisition of Pulau Pinang had, therefore, anomalous legal ramifications.

According to Rubin, the British realised the "effective acquisition" was unsupported by the normal legal underpinning. At the same time, it was felt necessary to exclude the exercise of jurisdiction in the island by the sultan of Kedah. Rubin further elaborates that:

In the absence of a cession or conquest the British seem to have had no clear basis in the International law of Europe of this time for the exclusion of Kedah's authority from Penang, at least until sufficient time had passed for the British to be able to claim that they had displaced his sovereignty by prescription. (Rubin in Salleh 2015, 243) 
Again, there was uncertainty as to the exclusion of Kedah's sovereignty over Pulau Pinang. It thus may be concluded that that the attributes of sovereignty over Pulau Pinang were achieved by mere assumption:

Best considered a conquest made in violation of the normal rules of belligerency of the time and the sovereignty itself passed by prescription when the British intention of permanent possession became fixed and the situation stabilized in conformity with the terms of the 1800 treaty. (Rubin in Salleh 2015, 244)

Rubin further delves on the issue of doubting British sovereignty over Pulau Pinang by drawing on the correspondence regarding slavery in Pulau Pinang, among other institutions; the letters of Mr. Dickens, a lawyer sent to Pulau Pinang as judicial officer who found he had no delegated judicial authority. He also finds that the very right of the Supreme Government to delegate that authority which was subject to some doubt, are of great interest.

Rubin explains that by first construing the situation of Pulau Pinang into a position in which an analogy between Pulau Pinang and deserted or unpopulated land could be drawn, Dickens arrived generally at the conclusion that Light's garrison brought with it English law to the area of the settlement but that the rest of Pulau Pinang was sort of jurisdictional non-man's land. However, on learning that Pulau Pinang had not been unpopulated in 1786, Dickens wrote another minute which he denied the force of his earlier line of argument and construed the earlier transaction into a cession to the EIC of full sovereignty in Pulau Pinang as of 1786. In Dicken's view, whatever the doubt surrounding the earlier transactions may have been, the fact was that the EIC possessed "sovereignty" (presumably intending to mean "political power") in Pulau Pinang and therefore ought to possess the legal rights of the sovereign. It is certain that by 1805 the British regarded themselves as possessing those rights; in that year Pulau Pinang was made a Presidency of India, essentially ruled by a private company and not formally by the British government. ${ }^{13}$

But, the question of classifying the reception of British judicial and legislative authority into Pulau Pinang was not definitely resolved until 1858. In the case of Regina vs. Willans, the decision was whether Light's troops constituted only a garrison and brought British law to Pulau Pinang only intra vires the settlement although it is explicit in regarding the 1786 transaction as a cession of Pulau Pinang as a whole to the company in trust for the Crown. This implies Light's authority "quasisovereign". The judge erroneously found no lex loci (either in fact or in law) "to have bound the territory of Penang". 
Referring to the logic and history in the decision, Rubin argues that it seems to have been part of the later British "retroactive rationale" of the acquisition by occupation of Pulau Pinang and was "therefore accepted as an accurate statement of the facts and their legal implications". It was:

An embarrassing fact and therefore ignored by Sir Benson, that between 1786 and 1800 British jurisdiction in Penang was assumed to involve judicial authority only over non-Europeans. Although the 20 years of British occupation of Penang had given the British authorities the feeling that Penang was rightly under British authority in all matters, when the judicial charter of 1807 was issued it was that charter that was conceived by contemporary officials to give local courts for the first time jurisdiction over British subjects. (Rubin in Salleh 2015, 245-246).

\section{The Kedah Sultans on the EIC Requests in the Light Letters}

Sultan Abdullah Mukarram Shah corresponded with Francis Light on various issues related to the "lease" of Pulau Pinang to EIC. In a letter dated 13th March 1785 (MS 40320/7, f. 148 1785) to Sultan Abdullah, Light mentioned about his mission to "request" Pulau Pinang, as instructed by the governor-general of EIC, as a place to repair and get supply for their boats. Light wrote in his letter, “...disuruh Raja Benggala mari pinta tempat pada ke bawah Duli Yang Dipertuan Yang Maha Mulia, Pulau Pinang itu dipohonkan hendak perbuat loji bubuh tinggal tempat kapal perang mudahlah hendak baiki kapal itu" (The king of Bengal had asked the Yang Dipertuan for Pulau Pinang to establish a factory/ workshop to dock warships to facilitate its repair).

From the letter, Sultan Abdullah knew that the request to occupy Pulau Pinang came from EIC and through Francis Light.

In the same letter, Francis Light promised that after Sultan Abdullah granted the permission to EIC to occupy Pulau Pinang, the company will protect Sultan Abdullah from the enemies whether the attack comes from the sea or from the land. Light makes his promise as follow, “...maka tatkala sudah dikurnia Pulau Pinang itu, barang yang jadi seteru Duli Yang Dipertuan dari sebelah laut dan sebelah darat jadi seterulah pada kompeni" (....and so after awarding Pulau Pinang, the enemies of the Yang Dipertuan coming from the sea and from land will be the enemies of the company). What this means is that Sultan Abdullah and his territory will be protected by EIC from his enemy, especially the Siamese and Burmese. No matter who the enemies are and from which direction the attacks come from, the EIC promised to protect Sultan Abdullah and the state of 
Kedah. This is the important condition that EIC offered to Sultan Abdullah as the compensation of acquiring Pulau Pinang from Kedah.

Five months later, in a copy of the letter from Sultan Abdullah Mukarram Shah to the governor-general of Bengal dated 30th August 1785, Sultan Abdullah mentioned that he was informed by Francis Light of the EIC governor-general's request for Pulau Pinang, as a port for their trading, to repair and to get the supplies of water and wood for their boats (MS 40320/5, f. 4 1785). Sultan Abdullah wrote:

Maka adalah mari Kapitan Light Dewa Raja maklumkan pada beta,
katanya sahabat beta pinta Pulau Pinang itu hendak beri wakil sahabat
beta kapitan Light Dewa Raja perbuat tempat dibubuh (ta-nga-kaf-alif?)
kompeni Raja Inggeris Pulau Pinang itu, tempat berjual beli dan baiki
kapal perang serta kemudahan cahari makanan daripada air, kayu.
(And so Captain Light Dewa Raja informed us saying that our friend had
asked for Pulau Pinang and through him for a place for the company to
trade and repair war ships and facilities to replenish water, timber.)

In the letter, Sultan Abdullah shows his understanding of the purposes from EIC to request Pulau Pinang and the role of Francis Light, who will be given the task as administrator of the island on behalf of EIC.

In the same letter, Sultan Abdullah mentioned his conditions to Light in occupying Pulau Pinang and if they agree to follow all terms and conditions stated by the sultan, they are allowed to enter the island. Sultan Abdullah then informed the governor-general, "jika sudah berbetulan dan kesukaan sahabat beta, dengan segera beri mari orang duduk di Pulau Pinang itu" (MS 40320/5, f. 4 1785) (if it is agreed upon by my friend and is in favour of the conditions, then bring people to settle on Pulau Pinang). Sultan Abdullah Mukarram Shah emphasised he would only allow the settling of Pulau Pinang by the EIC on the condition that the company agreed to fulfill the terms set by the sultan. The sultan had used the term "jika sudah berbetulan dan kesukaan" (if there is consensus and cordiality) which means that if the EIC agrees with the terms stated by the sultan.

In addition, this letter shows the role of Francis Light as a mediator for the negotiations of Pulau Pinang between Sultan Abdullah and governor-general of EIC. Sultan Abdullah wrote, "maka sudah beta nyatakan kepada kapitan itu segala kehendak beta, sampaikan pada sahabat beta" (MS 40320/5, f. 4 1785) (we therefore have stated to the kapitan our wish, relay this to our friend). 
Sultan Abdullah mentioned that he had informed Francis Light all his conditions to be discussed with governor-general of EIC.

Sultan Abdullah does not simply allow the EIC to occupy Pulau Pinang without fulfilling all the terms that he had initially sent to EIC. In fact, based on the original request from the governor-general, their initial intention was to have a harbour as a place to repair their boats and not to occupy the whole island for them to rule. This fact has been reminded again in a letter from Sultan Abdullah to Francis Light (MS 40320/10, f. 47 n.d.) where Sultan Abdullah wrote, "tempat hendak bubuh loji kecik tempat singgah baiki kapal perang tiada dipinta hendak buat negeri" (a small place as a harbour to repair vessels and not to request land to rule as a country).

Furthermore, Francis Light showed his effort to ensure that the acquisition of Pulau Pinang by EIC is materialised. He convinced Sultan Abdullah to release his control over Pulau Pinang to EIC due to the advantages and benefits that Sultan Abdullah and people of Kedah will get from this acquisition (see MS 40320/6, f. 50 n.d.). Among others, Sultan Abdullah will get the opportunity of business and trade in Pulau Pinang with valuable profit. The new EIC port in Pulau Pinang will generate more income and open more job opportunities to the people of Kedah.

Light wrote in his letter to convince Sultan Abdullah, “...segala rakyat Yang Maha Mulia yang miskin2 jadi kemudahan mencahari ayapan itu pun jadi kebajikan pada Yang Maha Mulia juga dan perniagaan Yang Maha Mulia pun tiada kurang makin lama bertambah" (MS 40320/6, f. 50 n.d.) (The poor subjects of the sultan be given the opportunity to feed themselves has become the sultan's function; as well as the increasing profitability of the sultan's business). Light attempts to persuade Sultan Abdullah by highlighting the positive impact of the new EIC business port in Pulau Pinang. However, the opening of the new port was disadvantageous, especially to the traders in Kota Kuala Kedah. The revenue from Kota Kuala Kedah has been declining due to the small number of traders going there compared to Pulau Pinang.

In addition, Francis Light advised Sultan Abdullah to disregard conditions that will make EIC reject the agreement. Light wrote in his letter to Sultan Abdullah, “...patik pohonkan Yang Maha Mulia khususkan barang yang patut jangan jadi berat sangat sampai pada Jenderal supaya boleh patik pergi sendiri khususkan patik ambil surat ikrar janji Jenderal" (...I appeal to his Majesty to include what is important only and not to make it complicated to the governorgeneral in Bengal so that I can specifically transmit his letter of undertaking) 
(MS 40320/6, f. 50 n.d.). In this letter, Francis Light suggested Sultan Abdullah not to make the conditions become very difficult for EIC to fulfil it. The main aim, according to Light, was to get the governor-general of EIC to sign the agreement with Sultan Abdullah. Light has already mentioned in the letter that EIC will help to protect Sultan Abdullah from the enemy coming from the sea, excluding the enemy coming from the land. However, Sultan Abdullah always reminded Francis Light to follow the initial conditions that were offered during the negotiations in 1785 where EIC promised to protect Kedah from the enemy coming from the sea and the land. Sultan Abdullah wrote to Light, “...demikianlah kehendaki beta dari mula sahabat beta mari pinta Pulau Pinang kata dengan suruh Jenderal itu sudah beta nyatakan kehendak beta sampai hari ini pun tiada beta ubahkan kata2 itu..." (MS 40320/7, f. 94 n.d.) (...this is what I wanted from the beginning from my friend who have asked for Pulau Pinang through the general. I have stated what I wanted. Till today I have not altered those words).

We could recall the frustration of Sultan Abdullah who sent many letters to the governor-general throughout the years through Francis Light to finalise the terms and conditions for the acquisition of the island. And still a reply was wanting. There was no pertinent feedback from Bengal even in the aftermath of Light landing in Tanjong Penaga in August of 1786. In a letter to Francis Light dated 13th February 1788, Sultan Abdullah complained this situation as he felt disappointed due to the unknown status of his request to EIC after many years of negotiations (see MS 40320/10, f. 70 1788). Sultan Abdullah wrote, "Maka khabar surat-surat itu tiada apa satu sahabat beta nyatakan mari kepada beta yang tentu seperti pinta beta..." (And so there was no news from the letters, no indication from our friend whom we had asked for...). Without the conclusion of this negotiation, the agreement on the acquisition of Pulau Pinang by EIC cannot be signed with Sultan Abdullah. As usual, the sultan kept reminding Francis Light to ensure that EIC agreed with the initial conditions that the sultan had offered when Francis Light was allowed to come and occupy Pulau Pinang (MS 40320/10, f. 69 n.d.). Sultan Abdullah wrote:

...kerana sekalian itu sudah dahulu beta nyatakan pada sahabat beta serta beta beri surat akan sahabat beta, beta pinta sahabat beta bawa sampaikan pada Jenderal Benggala, beta pinta tentukan seperti pinta beta itu maka tatkala sahabat beta hendak pergi ke Pulau Pinang, itu pun sahabat beta buat beri janji akan beta taruh. maka janji itulah beta pegang, tiadalah boleh beta dan sahabat beta ubahkan. 
(...we have already stated to our friend when we delivered him the letter to be forwarded to the governor-general in Bengal and when our friend is returning to Pulau Pinang, we keep the trust on what we agreed upon and so we and our friend are not allowed to amend it.)

In this letter, Sultan Abdullah emphasised to Light not to change any terms and conditions that have been agreed before.

In fact, the agreement was still pending and cannot be concluded due to the additional term and conditions from EIC. Sultan Abdullah wanted the EIC to keep their promise to follow what was agreed upon in 1785. The sultan cannot agree on the two new terms and conditions set by Bengal mentioned in his letter to Francis Light on 11th February 1789 (MS 40320/8, f. 44 1789). Sultan Abdullah wrote:

...maka ini sahabat beta nyatakan mari dua kehendak lain daripada kehendak beta nyatakan dari awal mulanya suka atau tiada suka beta sahabat beta pinta putuskan dinyata pergi maka perintah lain daripada kehendak beta dinyatakan dahulu itu keduanya itu tiadalah beta sukakan.

(And so our friend proposed two new conditions, differs from our earlier conditions, we want to know if you agree or disagree and we disagree with the two new conditions that differs from the earlier conditions.)

Unfortunately, in this letter, Sultan Abdullah did not mention the details on the new two conditions from EIC.

\section{Concluding Remarks}

The arguments presented in this article express the issue of the justification of the acquisition of Pulau Pinang by Francis Light. It is clear that there was no treaty, no signatures and no signatories. The 15th July landing and the 11th August 1786 hoisting of the British flag with renaming Pulau Pinang as "Prince of Wales Island" would be one of the greatest deceptions in history. A correct position on the question is important for a closure on the sovereignty and integrity of Kedah. This also leads to the nature of the lex loci in Pulau Pinang.

To reiterate among the main conditions that was highlighted by Sultan Abdullah was the role played by EIC to help Kedah to defend his territory from his enemy. This condition was again highlighted by the Sultan Abdullah to Light in his letter in May 1791 (MS 40320/9, f. 5 1791) but with slight changes. 
Sultan Abdullah urged Light to bring the matter to the EIC and emphasised on the inclusion of the condition in the agreement. In the letter, the sultan clearly mentioned that:

If the attack comes from the sea, it is the responsibility of the EIC to defend Kedah and Pulau Pinang with the support from Kedah in term of food and fund. If the attack comes from the land, it is the responsibility of the Sultan to defend Kedah with the financial aid from EIC.

This condition, even through 1791, was omitted by the company. Even the 1791 treaty was not signed by the sultan but by his representatives. The initial seizure of 1786 on Pulau Pinang by Light was attained without any written treaty signed by Sultan Abdullah and EIC. A closure over the issue of acquisition is significant to deconstruct and integrate the history of Pulau Pinang and Kedah. Historians of Pulau Pinang (so also of Kedah), as well as the consuming public, have been drawn by the avatar of 1786 so much so it has created a blind spot on historiography and sources. The historiography of Pulau Pinang and Kedah has been fragmented and the past of both polities distorted owing to questions of morality and illegality of the acquisition.

\section{Notes}

1. Portugal in particular was a small country with a population of only one million in 1500 and was importing slaves. See Tarling $(2001,23)$.

2. This section draws from the paper by Bashiran Begum, Noriah and Siti Junaidah (2007).

3. See US vs. Ushi Shioma ILR 21 (1954) (p. 82); Puccini vs. Commissioner-General of the Government of the Territory of Trieste (1961) ILR 40 (p. 43) and Netherlands vs. United States of America 2 R.I.A.A. 829 (1928) in Bashiran Begum, Noriah and Siti Junaidah (2007).

4. See ibid.

5. Bonney $(1971,53)$ suggests that the rejection was caused by Forrest's apparent lack of personal influence amongst members of the Kedah elite. See Bassett (1964).

6. See "Minute by G.G., 13 December 1786, SSR, 2" (as cited in Bonney 1971).

7. Bonney notes, citing Light's journal that the thinking on the confiscation of Dato' Seri Raja's property on his decease is not convincing as it would have applied in 1784 as well. It would appear more probable that if Dato' Seri Raja was interested in the lease of Pulau Pinang, then the fears uppermost in his mind would have been that of a Burmese invasion or a protracted Burmese-Siamese war. See "Footnote", p. 59.

8. See for example MS 40320/3, f. 31. 1787.

9. Bonney notes that the reply was in reference to the condition requiring Spanish $\$ 30,000$ a year as compensation of Sultan Abdullah's loss of his royal monopolies. 
10. This clause fulfilled Sultan Abdullah's requirement. See "Footnote" in Bonney $(1971,74)$.

11. Refer Salleh (2015).

12. The sultan was Sultan Ahmad Tajuddin Halim Shah II who reigned from 1804 to 1845.

13. According to Marcus Langdon, a chronicler and historian of Penang, in 1805, the island "was elevated from what was essentially an interim supply port on the China trade route to a self-governed EIC settlement, fourth only in importance to Calcutta, Madras and Bombay and reporting directly to the EIC's court of directors in London...it is also important to understand that this period represents governance by what was essentially a private company and not formally by the British government, though certainly under its general auspices. The presidency status was abolished in 1830 , just four years before the EIC's commercial operations were also brought to an end". See "Preface" in Langdon (2013).

\section{Bibliography}

Ahmad Murad Merican. 2019a. Representations of colonialism: The coming of Europeans to the Malay Archipelago. In Colonialism in the Malay Archipelago: Civilizational encounters, eds. Osman Bakar, Ahmad Murad Merican and Wan Ali Wan Mamat, 33-48. Kuala Lumpur: ISTAC-IIUM Publications.

2019b. Revisiting atas angin: A review of the Malay imagination of Rum, Ferringhi and the penjajah. Putrajaya: Perdana Leadership Foundation.

Bashiran Begum Mobarak Ali, Noriah Ramli and Siti Junaidah Muhamad. 2007. Lifting the veils: The mystique (mistake) of Penang legal history. Paper presented at the Seminar Ahmad Ibrahim, Petaling Jaya, Selangor, 21-22 August.

Bassett, D.K. 1964. British commercial and strategic interests in the Malay Peninsula. In Malayan and Indonesian studies, eds. J.S. Bastin and R. Roolvink, 122-140. Oxford: Oxford University Press.

1961a. English relations with Siam in the seventeenth century. Journal of the Malayan Branch of the Royal Asiatic Society (JMBRAS) 34(2): 90-105.

1961b. Thomas Forrest, an eighteenth century mariner. Journal of the Malayan Branch of the Royal Asiatic Society (JMBRAS) 34(2): 106-122.

1960. European influence in the Malay Peninsula, 1511-1786. Journal of the Malayan Branch of the Royal Asiatic Society (JMBRAS) 33(3): 9-31.

Bonney, R. 1965. Francis Light and Penang. Journal of the Malayan Branch of the Royal Asiatic Society (JMBRAS) 38(1): 135-158.

1971. Kedah 1771-1821: The search for security and independence. Kuala Lumpur: Oxford University Press.

Clodd, H.P. 1948. Malaya's first British pioneer: The life of Francis Light. London: Luzac.

Hooker, M.B. 1982. The law of the Straits Settlements: A commentary. Kuala Lumpur: Oxford University Press

Langdon, M. 2013. Penang the fourth presidency of India 1805-1830. Pulau Pinang, Malaysia: Areca Books. 
Maxwell, W.E. and Gibson, W.S. 1924. Treaties and engagement affecting the Malay States and Borneo. London: Truscott.

Mills, L.A. 1966. British Malaya 1824-67. Kuala Lumpur: Oxford University Press. 1925. British Malaya 1824-67. Journal of the Malayan Branch of the Royal Asiatic Society (JMBRAS) 33(3): 1-424.

MS 40320/3, f. 31. 1787. Letter from Sultan Abdullah Mukarram Shah to Francis Light. London: School of Oriental and African Studies.

MS 40320/5, f. 4. 1785. Copy of the letter from Sultan Abdullah Mukarram Shah to Governor-General of Bengal. London: School of Oriental and African Studies.

MS 40320/6, f. 50. n.d. Draft of the letter from Francis Light to Sultan Abdullah Mukarram Shah. London: School of Oriental and African Studies.

MS 40320/7, f. 148. 1785. Copy of the letter from Francis Light to Sultan Abdullah Mukarram Shah. London: School of Oriental and African Studies.

MS 40320/7, f. 94. n.d. Letter from Sultan Abdullah Mukarram Shah to Francis Light. London: School of Oriental and African Studies.

MS 40320/8, f. 44. 1789. Letter from Sultan Abdullah Mukarram Shah to Francis Light.

London: School of Oriental and African Studies.

MS 40320/9, f. 5. 1791. Letter from Sultan Abdullah Mukarram Shah to Francis Light.

London: School of Oriental and African Studies.

MS 40320/10, f. 47. n.d. Letter from Sultan Abdullah Mukarram Shah to Francis Light.

London: School of Oriental and African Studies.

MS 40320/10, f. 69. n.d. Letter from Sultan Abdullah Mukarram Shah to Francis Light.

London: School of Oriental and African Studies.

MS 40320/10, f. 70. 1788. Letter from Sultan Abdullah Mukarram Shah to Francis Light.

London: School of Oriental and African Studies.

Panikkar, K.M. 1953. Asia and Western dominance. Kuala Lumpur: The Other Press.

Rubin, A.P. 1974. The international personality of the Malay Peninsula. Kuala Lumpur: Penerbit Universiti Malaya.

Salleh Buang. 2015. Malaysian legal history: Cases and material. 2nd Ed. Kuala Lumpur: Dewan Bahasa dan Pustaka.

Shahrom Ahmat. 1984. Tradition and change in a Malay state: A study of economic and political development of Kedah 1878-1923. Kuala Lumpur: MBRAS.

Tarling, N. 2001. Imperialism in Southeast Asia: “A fleeting passing phase”. London/New York: Routledge.

Tregonning, K.G. 1965. The British in Malaya. Tuscon, AZ: University of Arizona Press. , ed. 1962. Papers on Malayan history. Singapore: Journal of South-East Asian History.

Winstedt, R.O. 1962. Malaya and its history. London: Hutchinson's University Library. 1935. A history of Malaya. Journal of the Malayan Branch of the Royal Asiatic Society (JMBRAS) 13(1): 1-270. 